\title{
Effects of grazing, sedimentation and phytoplankton cell lysis on the structure of a coastal pelagic food web
}

\author{
C. P. D. Brussaard, R. Riegman, A. A. M. Noordeloos, G. C. Cadée, H. Witte, \\ A. J. Kop, G. Nieuwland, F. C. van Duyl, R. P. M. Bak
}

Netherlands Institute for Sea Research, PO Box 59, 1790 AB Den Burg, Texel, The Netherlands

\begin{abstract}
The influence of grazing, sedimentation and phytoplankton cell lysis on the dynamics of a coastal pelagic ecosystem in the Southern Bight of the North Sea was studied during spring/summer 1992. Diatoms in the $>8 \mu \mathrm{m}$ size fraction dominated during early spring, due to size-differential control by microzooplankton. This diatom spring bloom became silicate depleted and declined by sedimentation. A Phaeocystis bloom developed in early summer. Phytoplankton cell lysis was the major loss factor for Phaeocystis, accounting for $75 \%$ of the decline of the bloom. Bacterial production was positively correlated with phytoplankton cell lysis, and bacterial carbon demand could be supplied by cell lysis. This illustrates the importance of phytoplankton cell lysis in providing energy for the microbial loop. A new method (nicotine addition technique) was used to estimate mesozooplankton grazing on microzooplankton. Mesozooplankton appeared to prefer microzooplankton as a food source, though there occasionally was substantial grazing on phytoplankton. We conclude that grazing and sedimentation, as well as cell lysis, are structuring mechanisms for algal bloom dynamics.
\end{abstract}

KEY WORDS: Phytoplankton cell lysis Grazing Pelagic food web Phaeocystis - Microbial loop

\section{INTRODUCTION}

Due to tidal and wind-induced turbulence and eutrophication, the Southern Bight is a well mixed, nutrient-rich part of the North Sea, characterized by strong seasonality in plankton productivity (Gieskes \& Kraay 1977. Cadée 1992). In spring a diatom bloom develops, which is generally followed by a bloom of the colony-forming prymnesiophycean Phaeocystis (Lancelot et al. 1991, Cadée 1992). In summer a succession of different diatom species forms 1 or 2 other peaks in phytoplankton biomass (Cadée 1986).

Algal bloom dynamics are determined by gain and loss factors. Since phytoplankton blooms convert large amounts of inorganic carbon and nutrients into organic biomass, insight into the processes underlying the decline of a phytoplankton bloom is of great importance for a better understanding of the ecosystem. Three main factors crucial for the dynamics of such ecosystems are grazing, sedimentation and phytoplankton cell lysis.

Micro- and mesozooplankton grazing may control the development and succession of phytoplankton directly by depressing phytoplankton standing stock or indirectly by mesozooplankton grazing on microzooplankton. Herbivorous metazoan grazing is not thought to be important in the termination of the diatom spring bloom because of the slow numerical response of mesozooplankton (Klein Breteler et al. 1982). The impact of metazoan grazing on Phaeocystis is not clear. Several studies showed significant grazing of the copepod genus Calanus on Phaeocystis (Tande \& Båmstedt 1987, Hansen et al. 1990), whereas others reported low grazing pressure on Phaeocystis by Calanus and other copepod genera (Hansen \& van Boekel 1991, Bautista et al. 1992). Estep et al. (1990) related grazing on Phaeocystis colonies by copepods to the physiological condition of the colonies. Grazing losses of Phaeocystis cells caused by microzooplankton can be substantial (Admiraal \& Venekamp 1986, Weisse \& Scheffel-Möser 1990). Copepods may indirectly favour Phaeocystis blooming by feeding on microzooplankton (Hansen et al. 1993).

Sedimentation can play a crucial role in the dynamics of phytoplankton. High vertical fluxes have been found during diatom blooms (Smetacek 1985, Riebesell 
1991), resulting in the removal of a substantial amount of nitrogen and phosphorus compounds from the euphotic zone. Sedimentation following Phaeocystis blooms can be high (Wassmann et al. 1990) or low (Wassmann 1994), depending on the physical characteristics of the specific ecosystem. In a turbulent coastal zone resuspension due to tidal currents is important, but the high concentration of suspended matter in the Southern Bight (Eisma \& Kalf 1987) may enhance particle aggregation (Riebesell 1991).

Reports on lysis of algal cells are few (Reynolds et al. 1982, van Boekel et al. 1992) but they show that cell lysis can be substantial at the end of a bloom. Phytoplankton cell lysis results in the release of the cell contents and therefore in an increase of nutrient-rich dissolved organic components in the watercolumn. This will enhance bacterial productivity (Laanbroek et al. 1985) and consequently the grazing on bacteria by heterotrophic ninonlageliates (Sherr et al. 1986, Weisse 1990). Grazing on heterotrophic nanoflagellates by ciliates (Sheldon et al. 1986, Pierce \& Turner 1992) and on microzooplankton by mesozooplankton (Wiadnyana \& Rassoulzadegan 1989, Gifford \& Dagg 1991, Turner \& Granéli 1992) will link the microbial food web with the conventional planktonic food web.

Our study focused on plankton loss factors in relation to the structure of a pelagic coastal zone food web in the Southern Bight of the North Sea; special emphasised is the blooming of Phaeocystis. An intensive sampling program was carried out during spring and summer 1992 in the Marsdiep area, south of the island Texel, The Netherlands. Two phytoplankton loss factors, autolysis and grazing, were measured, whereas the importance of sedimentation was deduced from the data. Grazing on microzooplankton was quantified by a new method.

\section{MATERIAL AND METHODS}

Investigation area and sampling. From mid-January to the end of September 1992, surface samples were taken during high tide at the NIOZ (Netherlands Institute for Sea Research) pier in the Marsdiep tidal inlet south of the island Texel, The Netherlands. The sampling location is a turbulent mixed tidal channel; consequently 1 depth was regarded as representative for the whole water column. We omitted data for $4 \mathrm{~d}$ from the data set, because on these days salinities were considered too low. Based on salinity data, we assumed that for all other days we sampled the same water mass.

Water analyses. Dissolved nutrients (orthophosphate, reactive silicate, ammonium-nitrogen, nitratenitrogen and nitrite-nitrogen) were determined on a TrAAcs 800 autoanalyzer (Technicon). Concentration of inorganic phosphate was determined according to Mangelsdorf (1972), concentration of ammonium according to Helder \& de Vries (1979) and the concentration of silicate according to Thomsen et al. (1983). For the determination of nitrate and nitrite, a procedure reducing nitrate to nitrite was used (see Technicon Industrial Method no. 818-87Ti Technicon 1987). Samples for inorganic phosphate, ammonium, nitrate and nitrite were stored before analyses at $-50^{\circ} \mathrm{C}$ and samples for silicate were stored in the dark at $4^{\circ} \mathrm{C}$. All samples were measured within 1 mo after collection.

Phytoplankton. Phytoplankton samples were fixed with buffered Lugol's solution. Phytoplankton cell numbers and species composition were determined, after concentration by sedimentation according to Utermöhl (1958), using a Zeiss inverted microscope. Phaeocystis colonies were collected by filtration over a $50 \mu \mathrm{m}$ mesh sieve and counted immediately after fixation.

Chlorophyil a (chl a) concentrations were used as an index of phytoplankton biomass. Samples for total chl a analysis were obtained by gentle filtration of water samples over a Whatman GF/F filter. Chl $a_{1}$ in different particle size fractions, was determined on $3 \mu \mathrm{m}$ and $8 \mu \mathrm{m}$ polycarbonate membrane filters (Poretics) according to Riegman et al. (1993). Filters were stored at $-50^{\circ} \mathrm{C}$ until analysis. The filters were destructed in $90 \%$ acetone with a homogenizer (Braun Melsungen) and chl a was analyzed fluorimetrically (Hitachi F2000) according to Holm-Hansen et al. (1965).

In order to compare phytoplankton biomass with zooplankton and bacterial biomass, chl a was converted into carbon using a conversion factor of 20 (average of factors reported by Gieskes \& Kraay 1977, and Kiørboe et al. 1990). Phaeocystis cell numbers were converted to carbon using the conversion factor $12.15 \mathrm{pg} \mathrm{C}$ per flagellate cell (average of factors given by Lancelot et al. 1991) and 14.2 pg C per colonial cell (Rousseau et al. 1990).

Autolysis of phytoplankton. Specific daily phytoplankton autolysis rates (expressed as \% particulate algal esterase activity released per day) were estimated according to a slightly modified method described by van Boekel et al. (1992). Dissolved esterase activity was measured in triplicate. The external standard (calibration curve) showed that the response factor was independent of the concentration in the range of 0 to $600 \mathrm{nM}$ fluorescein. The concentrations measured in the field never exceeded this range. A standard addition of fluorescein (Sigma) was used to quantify the influence of the matrix on the fluorescence signal for each individual sample.

We used a mean particulate esterase activity per chl a ratio of $5 \mathrm{nmol}$ fluorescein $(\mu \mathrm{g} \mathrm{chl} \mathrm{a)})^{-1} \mathrm{~h}^{-1}$ for estimation of particulate phytoplankton esterase activity in the field samples. From batch cultures of 13 algal 
species in different growth phases (Phaeocystis, Skeletonema costatum, Micromonas pusilla, Tetraselmis sp., Chaetoceros socialis, Ditylum brightwelli, Isochrysis galbana, Thalassiosira rotula, Lauderia borealis, Synechococcus sp., Rhodomonas sp., Thalassiosira weissflogii, Emiliana huxleyi), $10 \mathrm{ml}$ culture was sonificated for $20 \mathrm{~s}(2 \times 10 \mathrm{~s}$, on ice) and esterase activity (EA) was determined fluorimetrically. The EA/chl a ratio fluctuated considerably depending on species and growth phase. Stationarily growing cultures gave higher values than exponentially growing cultures. Phaeocystis matched the mean ratio of $5 \mathrm{nmol}$ fluorescein ( $\mu \mathrm{g} \mathrm{chl}$ a) ${ }^{-1} \mathrm{~h}^{-1}$. The number of bacteria in the algal cultures was always very low. The mean $\mathrm{EA} / \mathrm{chl}$ a ratio from axenic $D$. brightwellii cultures was comparable with the mean ratio from non-axenic $D$. brightwellii cultures, indicating an insignificant influence of the bacteria.

Bacterial biomass and production. Bacteria were collected on $0.2 \mathrm{\mu m}$ polycarbonate membrane filters (Poretics) and counted by the acridine orange direct count method (Hobbie et al. 1977). Cell numbers were converted into biomass considering the mean size of at least 100 randomly distributed cells (see procedure in van Duyl et al. 1990), using a factor of $0.22 \times 10^{-12} \mathrm{~g} \mathrm{C}$ $\mu \mathrm{m}^{-3}$ biovolume (Bratbak \& Dundas 1984).

Bacterial production was determined as ${ }^{3} \mathrm{H}$-leucine (L- $\left[4,5-{ }^{3} \mathrm{H}\right]$ leucine, 110 to $180 \mathrm{Ci} \mathrm{mmol}^{-1}$, Amersham) incorporation into bacterial biomass (Simon \& Azam 1989)

Zooplankton biomass and grazing. Nanoflagellates $(<20 \mu \mathrm{m})$ were fixed with glutaraldehyde $(1 \%$ final concentration). After gentle filtration $(<0.03$ bar $)$ of a $4 \mathrm{cc}$ water sample over $0.2 \mu \mathrm{m}$ Nuclepore filters (prestained in Sudan Black), the filters were stained with proflavine and mounted on slides (for exact procedures see van Duyl et al. 1990). Counting and sizing were done with epifluorescence microscopy. Conversion into biomass was based on a factor of $0.20 \times 10^{-12} \mathrm{~g} \mathrm{C}$ $\mu^{-3}$ biovolume, which is an intermediate of values determined by Fenchel (1982) and Børsheim \& Bratbak (1987).

Microzooplankton (tintinnids and naked ciliates) were counted in $20 \mathrm{ml}$ samples fixed with Lugol's solution (2.5\% final concentration) with an inverted microscope using Utermöhl's (1958) sedimentation technique. For both tintinnids and naked ciliates, biovolume was calculated from numbers per size category $(<20,20$ to 60,60 to 100 and $>100 \mu \mathrm{m})$ and converted into biomass using a conversion factor of $0.19 \times 10^{-12} \mathrm{~g}$ C $\mu \mathrm{m}^{-3}$ biovolume (Putt \& Stoecker 1989).

Mesozooplankton and the remainder of the microzooplankton were sampled by filtering $10 \mathrm{l}$ of seawater over a $50 \mu \mathrm{m}$ mesh sieve and fixed with an equal volume of $4 \%$ formalin. Copepods were identified to the species level, the other organisms to the class or genus level. Countings were done under a binocular dissecting microscope. Abundance was converted into biomass according to Nassogne (1972), Fransz \& van Arkel (1980) and Klein Breteler et al. (1982).

The heterotrophic dinoflagellate Noctiluca miliaris was counted together with mesozooplankton because of its large body size (200 to $600 \mu \mathrm{m})$, and the counts were converted to biomass using a factor of $0.2 \mu \mathrm{g} \mathrm{C}$ ind ${ }^{-1}$ (Uhlig \& Sahling 1990)

Growth and grazing rates of phytoplankton were estimated with the dilution method of Landry \& Hassett (1982) using total chl a as the measure of phytoplankton standing stock. Natural seawater samples were diluted with $0,50,80$ and $90 \% \mathrm{GF} / \mathrm{F}$ filtered seawater in $2.3 \mathrm{l}$ glass bottles. Bottles were incubated on a slowly rotating wheel under an in situ light and temperature regime. No nutrients were added to the dilution treatments, because this may result in substantial losses of oligotrich ciliates (Landry \& Hassett 1982, Gifford 1988) and because the growth coefficients may be artificially elevated and not representative of true in situ growth rates (Landry \& Hassett 1982). Samples were not screened to remove mesozooplankton, because this would have resulted in substantial losses of fragile zooplankton species and in substantial losses of Phaeocystis when present.

To estimate rates of ciliate mortality due to mesozooplankton grazing, we added nicotine $\left(\mathrm{C}_{10} \mathrm{H}_{14} \mathrm{~N}_{2}\right.$, Sigma $6.2 \mathrm{nM}$ final concentration) to undiluted natural seawater samples (2.3 l glass bottles). Nicotine is an alkaloid from the tobacco plant Nicotiana tabacum and can be used to paralyze the nervous system. As representatives of the mesozooplankton, 3 copepod species (adults, copepodites and nauplii of Temora longicornis, Pseudocalanus elongatus and Acartia clausi) were tested. After nicotine was added, the animals became paralyzed or died and stopped grazing on phytoplankton (Dunaliella sp., Micromonas sp., and ciliates (Oxyrrhis marina). In the bottles with no nicotine added, grazing by copepods was significant: compared with samples without copepods, ca $20 \%$ of the food standing stock at $t=24 \mathrm{~h}$ was grazed in $1 \mathrm{~d}$. The rotifer Brachionus plicatilis also stopped grazing on Rhodomonas sp. when nicotine was added. Nicotine at final concentration had no negative effect on the growth of phytoplankton compared to that in control cultures $(10$ species tested: Phaeocystis, Lauderia borealis, Isochrysis galbana, Ditylum brightwelliu, Dunaliella sp. Emiliania huxleyi, Thalassiosira rotula, Tetraselmis sp., Chaetoceros socialis, Rhodomonas sp.). As expected, neither ciliates (Diophrys sp., Euplotes mutagens, Uronema marinum, Ancistrumina sp.) nor heterotrophic dinoflagellates (Oxyrrhis marina and Noctiluca sp.) were influenced by nicotine at this final concentration. 
The nicotine-containing bottles, together with a control bottle (undiluted seawater without nicotine), were incubated on a slowly turning wheel ( $2 \mathrm{rpm}$ ) under an in situ photon flux density, light-dark cycle and temperature. Duplicate samples from each bottle were taken at the start and the end ( $t=24 \mathrm{~h}$ ) of each experiment. Micro- and mesozooplankton were enumerated and both growth rate and grazing rate were calculated according to Frost (1972).

\section{RESULTS}

\section{Phytoplankton dynamics}

Total chl a showed 3 major peaks with values around $50 \mu \mathrm{g} \mathrm{chl} \mathrm{al} \mathrm{I}^{-1}$ (Fig. 1A). The spring peak (Days 75 to 110) consisted mainly of diatoms (Fig. 2A, dominated by chains of Skcletonema costatum and Thalassiosira spp.). This is also reflected in the $>8 \mu \mathrm{m}$ chl a size fraction (Fig. 1B). Phaeocystis cell number showed 2 minor peaks, on Days 92 and 104, with abundances of $1.4 \times 10^{7}$ and $3.4 \times 10^{7} \mathrm{l}^{-1}$ (Fig. 2B). Phacocystis colonies were oniy found in low numbers (up to $1350 \mathrm{l}^{-1}$ on Day 104). The second chl a peak (Days 110 to 140) was dominated by Chaetoceros spp., Rhizosolenia spp., Leptocylindrus spp. (>8 $\mu \mathrm{m}$ size fraction) and Rhodomonas sp. ( 3 to $8 \mu \mathrm{m}$ size fraction). Blooming of Phaeocystis (Days 145 to 163 , Fig. 2B) resulted in a third chl a peak, with a total cell number of $6.9 \times 10^{7} 1^{-1}$ on Day 153, which was dominated by colonial cells. The number of Phaeocystis flagellate cells was an order of magnitude lower than that of Phaeocystis colonial cells and peaked on Day 156 (6x $10^{5} \mathrm{l}^{-1}$ ). During the Phaeocystis bloom peak, Phaeocystis cells constituted more than $80 \%$ of the phytoplankton carbon biomass. After the Phaeocystis bloom, a succession of other autotrophic flagellates and diatom species occurred.

During the development of the spring diatom bloom all macronutrients except nitrate dropped sharply (Fig. 3). Silicate concentration decreased to $0.25 \mu \mathrm{M}$ on Day 88 and stayed low during summer except for 2 small peaks (Days 104 and 157), when Phaeocystis dominated the phytoplankton. Inorganic phosphate concentration reached lowest levels $(<0.5 \mu \mathrm{M})$ from Day 121 until Day 156. Ammonium never reached concentrations below $1 \mu \mathrm{M}$ and fluctuated strongly. Nitrate concentration dropped steeply after Day 140 and reached lowest levels on Day 154 (0.2 $\mu \mathrm{M})$. During summer it stayed at low concentrations (around $1 \mu \mathrm{M}$ ).

Phytoplankton cell lysis rate (daily released EA expressed as \% of the particulate algal EA) was highest on Day 154 (43\% d ${ }^{-1}$; Fig. 2C), closely following the peak in Phaeocystis cell number. The high lysis rates found on Days 145 and 146 were the result of very low particulate EA, which becomes evident when cell lysis is expressed as $\mu \mathrm{g}$ cellular $C$ released $\mathrm{l}^{-1} \mathrm{~d}^{-1}$ (Fig. 4). During the Phaeocystis bloom (Days 145 to 165 ) the release of cellular $\mathrm{Cl}^{-1} \mathrm{~d}^{-1}$ was highest.

Specific net growth rates of phytoplankton and specific rates of zooplankton grazing on phytoplankton are presented in Fig. 5A. Algal gross growth rate increased from 0 to $0.4 \mathrm{~d}^{-1}$, equivalent to an increase from 0 to 0.57 doublings $\mathrm{d}^{-1}$. Net growth rates (obtained by subtracting grazing from gross growth rate) varied between -0.26 and $0.14 \mathrm{~d}^{-1}$. From Day 42 until Day 86 grazing rate increased from 0 to $0.37 \mathrm{~d}^{-1}$. The $>8 \mu \mathrm{m}$ size fraction increased in biomass, with a specific growth rate of $0.13 \mathrm{~d}^{-1}$ from Days 65 to 85 , comparable with the net growth rates $\left(0.09\right.$ to $\left.0.14 \mathrm{~d}^{-1}\right)$ derived from
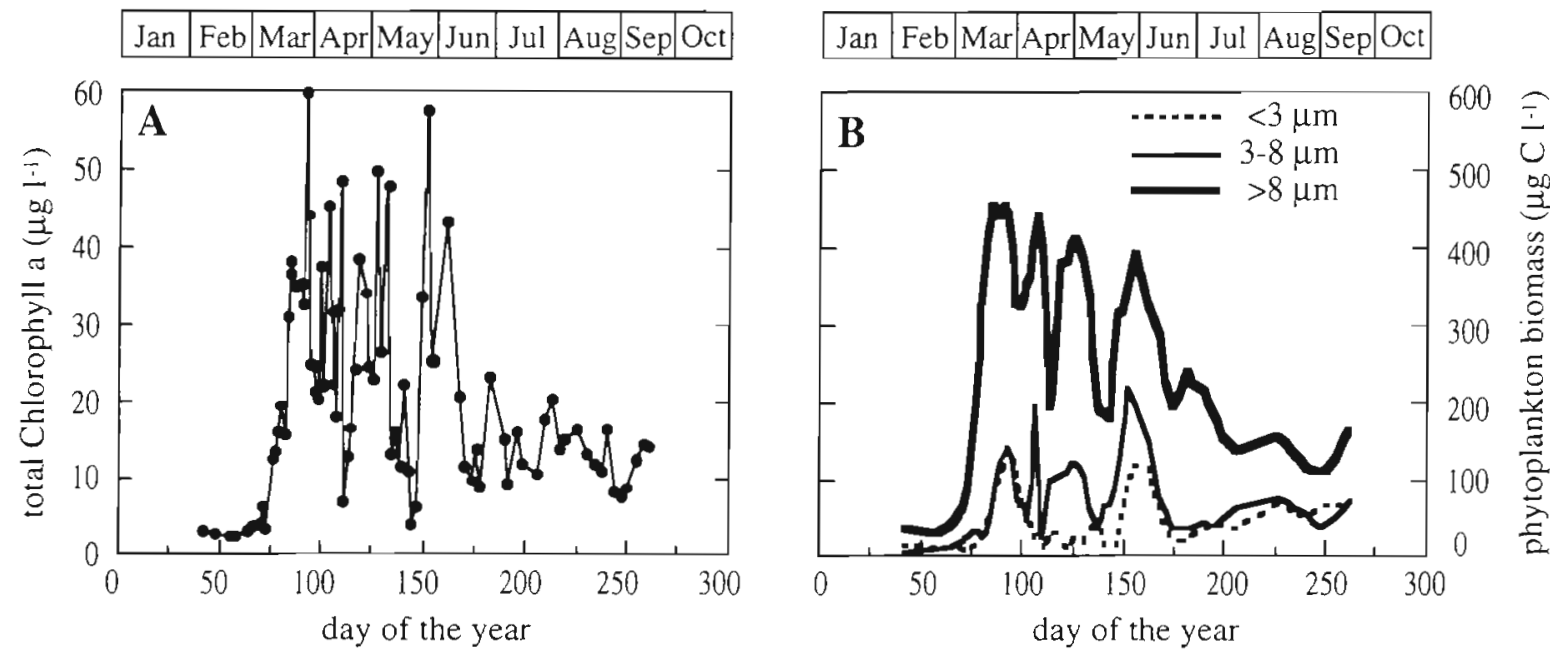

Fig. 1. Dynamics of (A) total chlorophyl a concentration $\left(\mu \mathrm{g}^{-1}\right)$ and $(B)$ biomass of different phytoplankton size fractions $(<3,3-8$ and $>8 \mu \mathrm{m}$, in $\mu \mathrm{g} \mathrm{C}^{-1}$ ) during 1992 in the Marsdiep area. Biomass was estimated using a C:chl a ratio of 20 


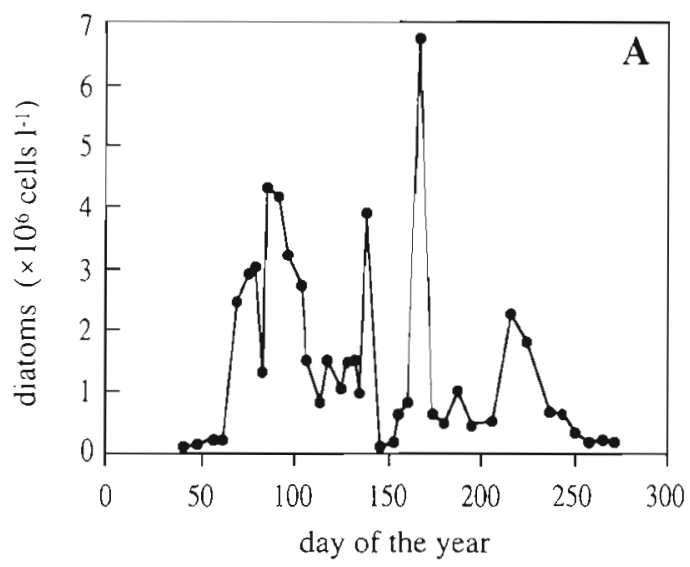

Fig. 2. Development of populations of (A) diatoms and (B) Phaeocystis (cells and colonies), and in the level of (C) phytoplankton cell lysis (\% particulate esterase activity released $\mathrm{d}^{-1}$ ) in water of the Marsdiep during spring and summer 1992
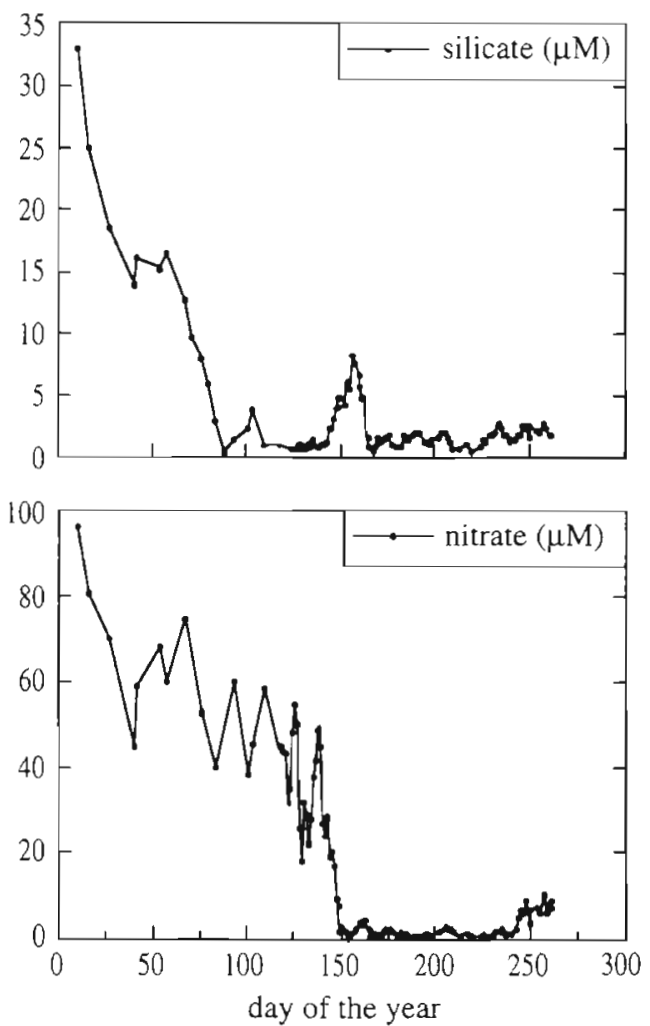
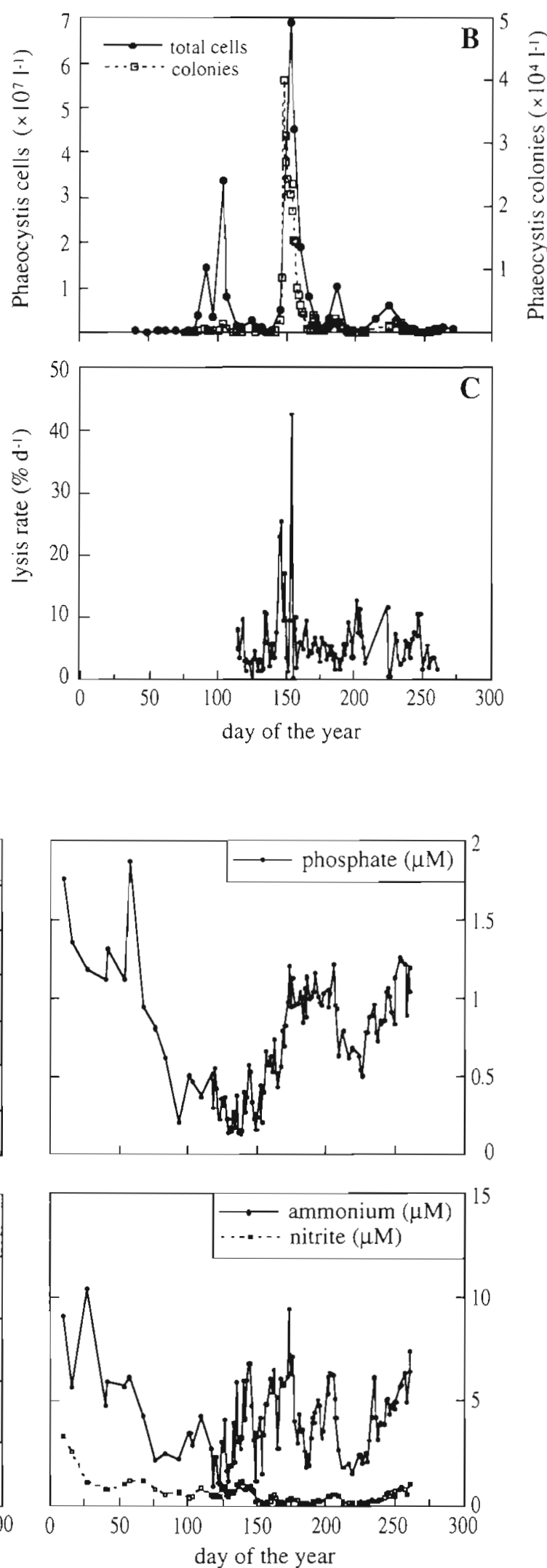

Fig. 3. Seasonal variations in reactive silicate, dissolved phosphate, nitrate-nitrogen, nitrite-nitrogen and ammonium-nitrogen (in $\mu \mathrm{M}$ ) in the water column of the Marsdiep area during 1992 


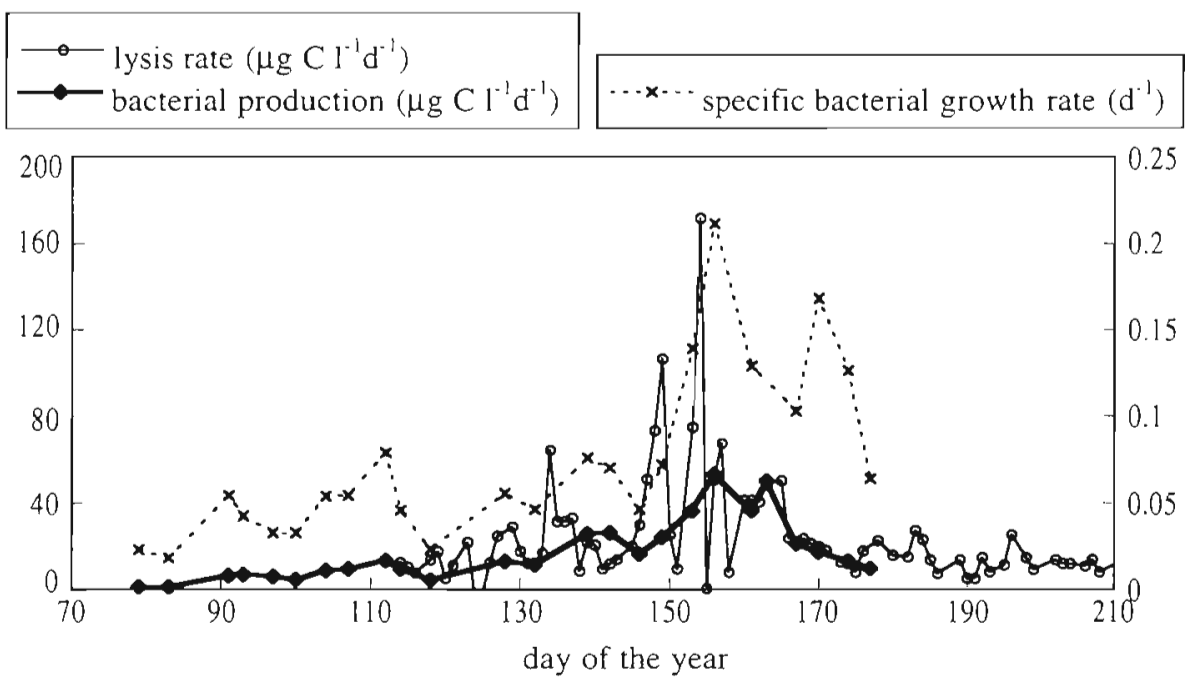

Fig. 4. Variations in the rate of bacterial production ( $\mu \mathrm{g} \mathrm{Cl} \mathrm{l}^{-1} \mathrm{~d}^{-1}$ ), of specific bacterial growth $\left(\mathrm{d}^{-1}\right)$ and of phytoplankton cell lysis ( $\mu \mathrm{g}$ cellular $\mathrm{C}$ released $\mathrm{I}^{-1} \mathrm{~d}^{-1}$ ) during 1992 in the Marsdiep area
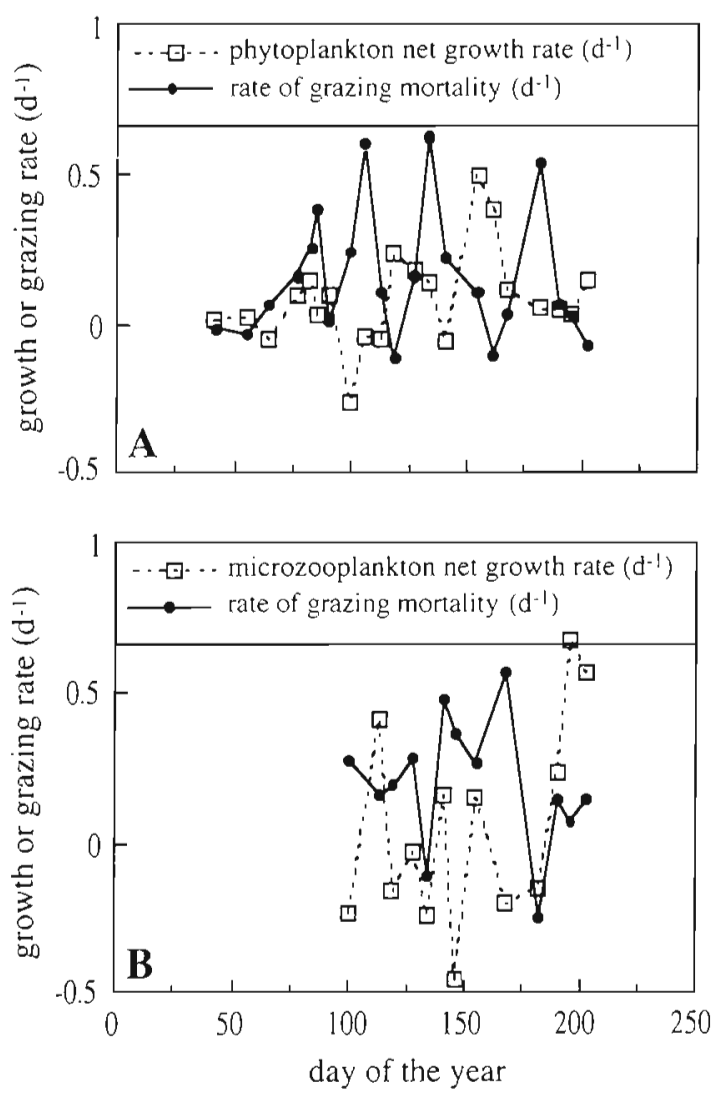

Fig. 5. Fluctuations in (A) specific net algal growth rate and specific algal mortality rates due to herbivorous grazing, $(B)$ specific microzooplankton net growth rate and specific microzooplankton mortality rates due to grazing by mesozooplankton during 1992 in the Marsdiep area. Grazing on phytoplankton was determined by the dilution technique according to Landry \& Hasset (1982), whereas mesozooplankton grazing on microzooplankton was determined by the nicotine addition technique (present study). Nicotine stopped mesozooplankton grazing on microzooplankton (see 'Methods') the dilution experiments during that period. The second peak in grazing rate (Day 106) resulted in negative net growth rate. Grazing rate on Day 1.34 peaked together with chl a (Fig. 1A) and reached levels of 0.62 $\mathrm{d}^{-1}$. During the Phaeocystis bloom, grazing pressure was rather low (max. $0.1 \mathrm{~d}^{-1}$ ). After the Phaeocystis bloom grazing peaked again on Day 182, whereas net growth rates decreased $\left(0.03 \mathrm{~d}^{-1}\right.$ on Day 196$)$.

\section{Bacterio- and protozooplankton dynamics}

Until Day 90 both bacterioplankton and heterotrophic nanoflagellate ( $\mathrm{HNF}$ ) biomass stayed relatively constant at low levels $\left(<100 \mu \mathrm{g} \mathrm{C}^{-1}\right.$; Fig. 6A). A rapid increase in bacterioplankton biomass, closely followed by an increase in HNF biomass, occurred after Day 90. Bacterioplankton showed a major peak on Day 142 (370 $\mu \mathrm{g} \mathrm{C}^{-1}$ ). HNF biomass peaked twice, first on Day $104\left(275 \mu \mathrm{g} \mathrm{C}^{-1}\right)$ and again on Day 156 (325 $\mu \mathrm{g} \mathrm{C}$ $1^{-1}$ ). Bacterial production (Fig. 4) steadily increased from Day 80 until Day 156, reaching a maximum of $53 \mu \mathrm{g} \mathrm{C}^{-1} \mathrm{~d}^{-1}$. The peak in specific bacterial growth rate (derived from bacterial production and bacterial biomass, max. $0.21 \mathrm{~d}^{-1}$ ) coincided with bacterial production and both closely followed the peak in lysis rate

\section{Micro- and mesozooplankton dynamics}

Biomasses of Noctiluca sp., microzooplankton (ciliates) and mesozooplankton are presented in Fig. 6B. Noctiluca sp. biomass peaked on Days 150 and 170 , reaching levels of 150 and $200 \mu \mathrm{g} \mathrm{C} \mathrm{l}^{-1}$, respectively. Microzooplankton biomass fluctuated strongly, with 2 major peaks of ca $300 \mathrm{H} \mathrm{Cl}^{-1}$ on Days 99 and 163. A strong de- 

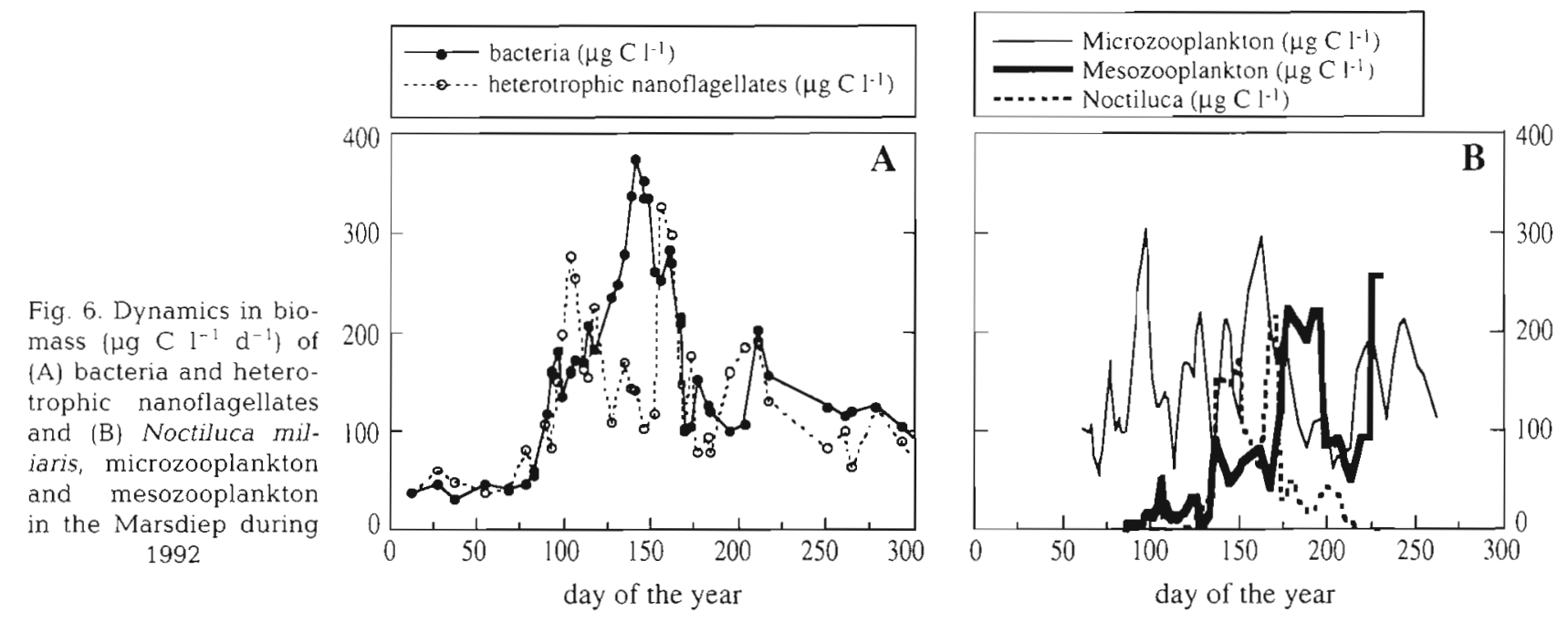

cline in biomass occurred after Day 163, reaching a level of around $100 \mu \mathrm{g} \mathrm{C}^{-1}$, which lasted 4 wk. Microzooplankton was dominated by the naked ciliates during the entire study period. Peaks in tintinnid biomass of $70 \mu \mathrm{g} \mathrm{C}$ $1^{-1}$ were found on Days 95, 155 and 215.

Mesozooplankton was not seen until Day 85, after which it developed in 3 stages. The first stage, with low biomass $\left(20 \mu \mathrm{g} \mathrm{Cl}^{-1}\right.$ ), lasted until Day 130 . The second stage (ca $80 \mu \mathrm{g} \mathrm{C}^{-1}$ ) was reached on Day 135 and lasted 5 wk. After a sharp increase, mesozooplankton biomass peaked on Day $190\left(225 \mathrm{\mu g} \mathrm{C} \mathrm{l}^{-1}\right)$. In general, copepods dominated the mesozooplankton biomass; the copepod species Pseudocalanus elongatus and Temora longicornis dominated in spring and Acartia clausi during summer, in accordance with the findings of Fransz \& van Arkel (1983) and Fransz et al. (1991). Polychaete larvae were not found earlier than Day 125.

Specific net growth rate of microzooplankton (Fig. 5B) was often negative, which in most cases was the result of relatively heavy grazing by mesozooplankton. Microzooplankton net growth peaked on Day 113 (0.41 $\left.\mathrm{d}^{-1}\right)$ and Day 196 (0.67 $\left.\mathrm{d}^{-1}\right)$. Mesozooplankton grazing on microzooplankton was low on Day 134 $\left(<0 \mathrm{~d}^{-1}\right)$ and after Day $168\left(\max .0 .14 \mathrm{~d}^{-1}\right)$.

\section{DISCUSSION}

\section{Diatom spring bloom}

The increased grazing of microzooplankton on small phytoplankton during late winter - early spring combined with the rapid numerical response of the microzooplankton (Banse 1982, Verity 1985, Burkill et al. 1987) resulted in size-differential grazing control, which is described in more detail by Riegman et al. (1993). The larger phytoplankton species (> $8 \mu \mathrm{m}$ chl a size fraction, mainly diatoms) escaped microzooplankton grazing and gave rise to the diatom spring bloom. Microzooplankton grazing balancing the growth of the nanophytoplankton size fraction during early spring has also been reported for Chesapeake Bay (USA) by McManus \& Ederington-Cantrell (1992).

Assuming a 30\% growth efficiency for microzooplankton (Rassoulzadegan 1982, Rivier et al. 1985, Verity 1985, Riegman et al. 1993), the net increase in microzooplankton biomass could be explained by herbivorous grazing. Assuming also a growth efficiency of $30 \%$ for mesozooplankton (Sheldon et al. 1986), mesozooplankton grazing on microzooplankton $\left(0.27 \mathrm{~d}^{-1}\right)$ was sufficient to explain the net increase in mesozooplankton biomass. Copepods prefer microzooplankton to phytoplankton (Wiadnyana \& Rassoulzadegan 1989, Stoecker \& Capuzzo 1990) and egg production of copepods feeding on ciliates is significantly higher than that of copepods feeding on phytoplankton (Stoecker \& Egloff 1987, White \& Roman 1992). The low grazing pressure on phytoplankton at the end of the spring bloom furthermore suggests that mesozooplankton grazing was not important for the decline of the diatom spring bloom. The low grazing impact on phytoplankton ( $<5 \%$ of phytoplankton standing stock) by copepods during diatom spring blooms in the Southern Bight of the North Sea (Fransz \& Gieskes 1984, Nielsen \& Richardson 1989) is thought to be due to the small size of the overwintering population of neritic copepods and to their low numerical response at the relatively low temperature present during spring (Klein Breteler et al. 1982).

Unfortunately, phytoplankton cell lysis was not measured during the diatom spring bloom. However, van Boekel et al. (1992) found no increase in lysis rate at the end of the diatom spring bloom. Also, bacterial production showed only a slight increase, indicating 
the minor importance of cell lysis (present study). Therefore, it is unlikely that autolysis of diatom cells was responsible for the decline of the spring bloom. Sedimentation must be the loss factor inducing the decline of the diatom bloom. High sedimentation of diatoms during spring blooms has been reported by Smetacek (1985) and Peinert et al. (1982). In general, diatom sinking rates increase dramatically upon nutrient depletion (Bienfang 1981, Riebesell 1989). During our study the diatom bloom, dominated by Skeletonema costatum, became silicate depleted. Riebesell (1989) found enhanced sinking of ungrazed Skeletonema costatum and Thalassiosira spp. cells during the diatom spring bloom. These high sinking rates (max. $4 \mathrm{~m} \mathrm{~d}^{-1}$ ) resulted from the formation of highly species-specific aggregates (Passow 1991, Riebesell 1991), enhancing sedimentation (Kranck \& Milligan 1988) and leading to a rapid disappearance of the diatom population. Assiming daily losses of $5 \%$ due to cell lysis and assuming no growth of diatoms after the peak in cell number (Day 92), daily sedimentation losses varied between 4 and $15 \%$ of diatom standing stock per day. This is low compared to values (up to $50 \% \mathrm{~d}^{-1}$ ) reported by Riebesell (1989) and Passow (1991). In their studies the mixing of the water column was considerably reduced, probably resulting in enhanced sedimentation of the diatom population. In any case, the removal of organic matter from the water column to the sediment will have inhibited the development of the pelagic microbial food chain.

\section{Transition period}

Reduced grazing on phytoplankton at the end of the spring bloom resulted in an increased biomass of the $<8 \mu \mathrm{m}$ phytoplankton size fraction. Phaeocystis cells also increased in number, but this did not result in the bloom of Phaeocystis normally occurring at this time of the year (Cadée \& Hegeman 1986, van Boekel et al. 1992). Relatively low temperatures $\left(6\right.$ to $\left.8^{\circ} \mathrm{C}\right)$ during this period may have led to low Phaeocystis growth rates (Kayser 1970 , Grimm \& Weisse 1985). Peperzak (1993) observed no Phaeocystis colony formation below a mean watercolumn daily irradiance of $100 \mathrm{Wh} \mathrm{m}^{-2} \mathrm{~d}^{-1}$ (threshold value). We calculated mean water-column photosynthetically active radiation according to Peperzak (1993), assuming a mean depth of $18 \mathrm{~m}$ for the wellmixed coastal area under study. Because light attenuation coefficients are fairly variable, we used coefficients varying between 0.35 and $1 \mathrm{~d}^{-1}$ (from Veldhuis et al. 1986, Lancelot \& Mathot 1987, Peperzak 1993). Until Day 90 the threshold of $100 \mathrm{Wh} \mathrm{m}^{-2} \mathrm{~d}^{-1}$ was not reached for more than 2 consecutive days. A strong drop in irradiance (below threshold) after Day 103 probably inhibited the formation of colonies and prevented the blooming of Phaeocystis in the transition period

Increased grazing impact (from $0.01 \mathrm{~d}^{-1}$ on Day 91 to $0.6 \mathrm{~d}^{-1}$ on Day 106, corresponding to an increase from 5 to $260 \mu \mathrm{g} \mathrm{Cl}^{-1} \mathrm{~d}^{-1}$ ) seemed to be the major loss factor for the decline in Phaeocystis cells. Despite increased microzooplankton grazing on phytoplankton and HNF, microzooplankton biomass was reduced by mesozooplankton grazing (at a rate of ca $0.27 \mathrm{~d}^{-1}$, corresponding to $60-100 \mu \mathrm{g} \mathrm{Cl}^{-1} \mathrm{~d}^{-1}$ ). Since from Days 106 to 119 zooplankton grazing on phytoplankton decreased to zero and gross growth of microzooplankton remained high (max. $0.57 \mathrm{~d}^{-1}$ ), it appears that the relative importance of HNF as a food source for microzooplankton increased. Pierce \& Turner (1992) reported in a review that marine planktonic ciliates are selective grazers which can discriminate not only prey sizes, but also the nutritional qualities of the prey. HNF biomass declined after Day 107, and consequently bacteria escaped grazing by HNF, resulting in an increase of bacterial biomass. HNF grazing rates during this period were relatively low (Bak unpubl. data).

The low growth rate of microzooplankton and the relatively low microzooplankton biomass on Day 135 forced the mesozooplankton to switch their diet from microzooplankton to phytoplankton. Since copepods are able to capture and handle food particles actively using sensory inputs for detection, capture and ingestion (Paffenhöfer 1982), they can actually switch from one food source to another. Assuming a mesozooplankton growth efficiency of $30 \%$, the observed increase in mesozooplankton could easily be supported by the phytoplankton losses due to grazing

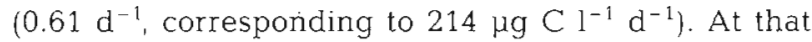
time, diatoms (dominated by Chaetoceros spp., Leptocylindrus spp. and Rhizosolenia spp.) constituted more than $80 \%$ of the phytoplankton stock. Grazing and cell lysis could account for all of the phytoplankton losses (mainly from the $>8 \mu \mathrm{m}$ size fraction), so sedimentation apparently was of no importance. Riebesell (1989) also found that sedimentation was not a significant loss factor for Chaetoceros spp. and Leptocylindrus minimus. Our data suggest that diatoms could not compensate for their losses due to silicate depletion. Because of the lowered phytoplankton biomass and increased microzooplankton biomass after Day 135, mesozooplankton switched back to grazing on microzooplankton.

Based on the grazing losses of microzooplankton and phytoplankton between Day 128 and 150, an increase in mesozooplankton biomass of at least $800 \mathrm{\mu g} \mathrm{Cl}^{-1}$ was estimated (assuming 30\% growth efficiency). However, an increase of only $100 \mathrm{\mu g} \mathrm{Cl}^{-1}$ was observed. This implies that most of the mesozooplankton was grazed down, probably by other mesoplanktonic species, through cannibalism (Daan 1989) or by macroplanktonic predators 
(Turner et al. 1983, Kuipers et al. 1990). Noctiluca miliaris increased sharply around this time. Although heterotrophic dinoflagellates are capable of grazing on prey their own size (Schaumann et al. 1988, Hansen 1992) and $N$. miliaris is known to be polyphagous without any food preference (Uhlig \& Sahling 1990), N. miliaris is not thought to be an important predator of mesozooplankton during this period of high $N$. miliaris biomass. High abundance of $N$. miliaris in the upper water column is thought to be the result of aging cells (Schaumann et al. 1988), which are generally inactive or starving (Uhlig \& Sahling 1990). Physical conditions (e.g, wind) may aid in generating a $N$. miliaris patch. In this study, many empty cells were observed microscopically, indicating a poor condition of $N$. miliaris The highest grazing on mesozooplankton by $N$. miliaris must have occurred slightly before the mass appearance of $N$. miliaris in the surface water when the organism was still in good condition (Schaumann et al. 1988).

\section{The Phaeocystis bloom}

A period of 2 wk (Days 134 to 150 ) with continuously high mean water-column daily irradiance must have enhanced the formation of Phaeocystis colonies (Peperzak 1993). For Days 140 to 155, gross growth rates of 0.5 to $0.6 \mathrm{~d}^{-1}$ were calculated for Phaeocystis cells. Since the phosphate concentration during the start of the bloom was rather low $(0.2$ to $0.6 \mu \mathrm{M})$, this situation is in good agreement with that found for Phaeocystis growth rates by Veldhuis \& Admiraal (1987; 0.4 to $0.5 \mathrm{~d}^{-1}$ ) and van Boekel (1992; 0.3 to $0.6 \mathrm{~d}^{-1}$ ) under conditions of low phosphate concentration and sufficient nitrate.

Riegman et al. (1992) showed that the formation of Phaeocystis colonies is stimulated by nitrate. Our data suggest that the Phaeocystis bloom became limited due to nitrate depletion. The subsequent increase in Phaeocystis cell lysis after nitrate depletion has also been observed by van Boekel et al. (1992). Increased lysis rates during the blooming of Phaeocystis were preceded by an increased number of nearly empty colonies ('ghost colonies').

The method used for measuring autolysis assumes that release of esterase in the water was exclusively attributable to phytoplankton. Zooplankton sloppy feeding as a potential source of esterase release was negligible, because during periods with high grazing on phytoplankton (e.g. Days 134 and 182) and on zooplankton (e.g. Days 141 and 168) there was no increase in released esterase. Since declining bacterial and zooplankton biomass did not result in enhanced release of esterase, autolysis of these organisms also seems to have been negligible.
Due to the high biomass of Phaeocystis and increased cell lysis rates, daily phytoplankton losses due to autolysis were high during and especially at the end of the Phaeocystis bloom. Bacteria responded to the release of nutrient-rich organic cell components by increasing their daily production. We assumed a bacterial carbon conversion efficiency of 0.35 , which is an intermediate of values reported for phytoplankton cell debris and lysis products (Biddanda 1988, van Wambeke 1994). Thus, the released phytoplankton cellular carbon accounted for $43 \%$ of the bacterial carbon demand during the Phaeocystis bloom (integrated over Days 145 to 168). However, cellular C: chl a ratios of 29 (Lancelot et al. 1991) and 27 (Davies et al. 1992) have been reported for Phaeocystis, slightly higher than the ratio used in this study. With a C:chl a ratio of 29 , Phaeocystis cell lysis could account for $74 \%$ of the bacterial carbon demand. The carbon release due to cell lysis did not include carbon from the mucous matrix around Phaeocystis cells (colonies). To include carbon from the colonial matrix we used a $C$ :chl a ratio of 70 (Baumann et al. 1994) and assumed a total of 50 to $75 \%$ carbon in Phaeocystis debris utilized by bacteria. The recalculated carbon release constituted 83 to $125 \%$ of the carbon needed for bacterial production. Phytoplankton cell lysis appeared to be an important source of organic carbon for the microbial food web. We estimated that $48 \%$ of gross phytoplankton production (derived from phytoplankton gross growth rate and phytoplankton standing stock) was channeled to bacteria during the Phaeocystis bloom. This is in good agreement with values measured in the Belgian coastal pelagic (Joiris et al. 1982, Lancelot \& Billen 1984). The correlation between autolysis and bacterial production was especially good for nitrogen. Assuming a C:N ratio of 6 and 4 for Phaeocystis cells (Lancelot et al. 1986, Baumann et al. 1994) and bacteria (Fukami et al. 1981) respectively, the bacterial nitrogen demand could be satisfied by Phaeocystis cell lysis. However, Phaeocystis cell lysis could only account for $53 \%$ of the total bacterial phosphorus demand due to the relatively low C:P ratio for bacteria (assuming C:P ratios of 106 and 40 for Phaeocystis cells and bacteria respectively).

The Phaeocystis bloom declined at a daily mortality rate of ca $0.15 \mathrm{~d}^{-1}$ (Days 153 to 168), in good agreement with the rates reported by Lancelot \& Mathot (1987). Assuming no growth of Phaeocystis after the peak in cell number, cell lysis accounted for $75 \%$ of this decline. Grazing could account for the other $25 \%$, so sedimentation seemed of no or only minor importance for the decline. This supports the idea that mineralization of Phaeocystis in turbulent coastal ecosystems tends to be pelagic rather than benthic (Wassmann 1994). 
Field studies in the southern North Sea report Phaeocystis to be an inadequate food source for the copepods Temora longicornis (Hansen \& van Boekel 1991), Calanus helgolandicus, Pseudocalanus elongatus and Oithona sp. (Bautista et al. 1992). Hansen et al. (1993) showed that in the presence of protozoa, $T$. longicornis did not feed on Phaeocystis but selected protozoans. Consequently the grazing impact on Phaeocystis must be due to microzooplankton (ciliates), which are known to graze substantially on single Phaeocystis cells (Admiraal \& Venekamp 1986, Weisse \& Scheffel-Möser 1990, Hansen et al. 1993). Microzooplankton growth at $30 \%$ growth efficiency cannot be explained by grazing on phytoplankton only (max. $0.1 \mathrm{~d}^{-1}$ ). Rassoulzadegan (1982) showed that growth efficiency of the ciliate Lohmanniella spiralis was temperature dependent; however, even at a growth efficiency of $45 \%$ (corresponding to the average temperature of $17^{\circ} \mathrm{C}$ during the Phaeocystis bloom) microzooplankton growth cannot be explained by grazing on phytoplankton only. Thus, it is likely that microzooplankton also grazed on the increasing HNF population. Severe grazing on bacteria resulted in a sharp increase in HNF biomass and a decline in bacterial biomass. However, grazing on bacteria was not enough to explain the increase in HNF biomass. Picoautotrophs were found to decrease in biomass during this period, likely due to grazing by HNF (Caron et al. 1991, Kuosa 1991). For the Dogger Bank area (southern North Sea), Nielsen et al. (1993) calculated that the HNF carbon demand could only be satisfied when including grazing on picoplankton.

Mesozooplankton grazing impact on microzooplankton was high $\left(0.25\right.$ to $\left.0.56 \mathrm{~d}^{-1}\right)$ during the Phaeocystis bloom. Assuming a growth efficiency of $30 \%$ for mesozooplankton, the grazing losses of microzooplankton (55 to $114 \mu \mathrm{g} \mathrm{C} \mathrm{l}^{-1} \mathrm{~d}^{-1}$ ) would potentially result in a daily increase of mesozooplankton biomass of at least $18 \mu \mathrm{g} \mathrm{C} \mathrm{l}^{-1}$. However, mesozooplankton biomass

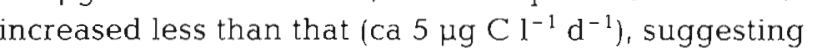
that grazing on mesozooplankton was important. From Day 165, medusae were observed in the water column. Turner et al. (1983) and Båmstedt (1990) suggested that predation by gelatinous carnivores (ctenophores and medusae) on copepods is substantial.

\section{Summer}

Microzooplankton biomass attained high levels at the end of the Phaeocystis bloom due to the increased importance of the microbial food web. The high impact of grazing on microzooplankton by mesozooplankton linked the microbial food web with the conventional planktonic food web. Throughout summer, mesozoo- plankton development was strongly related to microzooplankton population dynamics. Our data suggest that, during summer, microzooplankton grazed on both small phytoplankton and HNF.

Silicate and nitrate concentrations were low during summer, preventing the blooming of diatoms and Phaeocystis. Consequently total phytoplankton biomass was relatively low, with only small variations. Community productivity was based on ammonium utilization, resulting in an increased fraction of phytoplankton biomass due to cells $<8 \mu \mathrm{m}$.

\section{CONCLUSIONS}

Grazing, sedimentation and phytoplankton cell lysis alternated as deciding factors in the structure of the pelagic food web in the Marsdiep arca during spring and summer 1992. Due to size-selective grazing by microzooplankton, and low early spring mesozooplankton abundance, large algae (>8 $\mu \mathrm{m}$ diameter) escaped grazing and increased in biomass. Sedimentation caused the silicate-depleted diatom spring bloom to decline, removing nutrient-rich organic matter from the water column.

The development of mesozooplankton was facilitated through grazing on microzooplankton. The influence of mesozooplankton on the succession of phytoplankton, therefore, was mainly indirect. Only occasionally was it observed to directly control phytoplankton development. Net increase in mesozooplankton biomass was often less than that estimated from grazing rates, suggesting that grazing on mesozooplankton occurred.

Grazing on Phaeocystis accounted for $25 \%$ of the decline of the Phaeocystis bloom, and phytoplankton cell lysis for the other $75 \%$. Phytoplankton cell lysis appeared to be the third major loss factor determining algal bloom dynamics. It was an important source of organic carbon for the microbial loop.

Acknowledgements. The idea to use nicotine to stop mesozooplankton grazing evolved from a stimulating discussion with Bouwe Kuipers. His wife used tobacco extracts to kull snails in her vegetable garden. We thank him also for his support. We thank Ton Mosh, Jan Hegeman and Jan van Ooyen for their assistance. This study was supported by the EC within the framework programme STEP (contract no. STEP-CT90-0062).

\section{LITERATURE CITED}

Admiraal W, Venekamp LAH (1986) Significance of tintinnid grazing during blooms of Phaeocystis pouchetii (Haptophyceae) in Dutch coastal waters. Neth J Sea Res 20(1): 61-66 
Bamstedt U (1990) Trophodynamics of the scyphomedusae Aurelia aurita. Predation rate in relation to abundance, size and type of prey organism. J Plankton Res 12(1): $215-229$

Banse K (1982) Cell volumes, maximal growth rates of unicellular algae and ciliates, and the role of ciliates in the marine pelagial. Limnol Oceanogr 27(6):1059-1071

Baumann MEM, Lancelot C. Brandini FP. Sakshaug E, John DM (1994) The taxonomic identity of the cosmopolitan prymnesiophyte Phaeocystis: a morphological and icophysiologican approach. J mar Syst 5:5-22

Bautista B, Harris RP, Tranter PRG, Harbour D (1992) in situ copepod feeding and grazing rates during a spring bloom dominated by Phaeocystis sp. in the English Channel. J Plankton Res 14(5):691-703

Biddanda BA (1988) Microbial aggregation and degradation of phytoplankton-derived detritus in seawater. II. Microbial metabolism. Mar Ecol Prog Ser 42:89-95

Bienfang PK (1981) Sinking rates of hetrogeneous, temperate phytoplankton populations. J Plankton Res 3(2):235-253

Børsheim KY, Bratbak G (1987) Cell volume to cell carbon conversion factors for a bacterivorous Monas sp. enriched from seawater. Mar Ecol Prog Ser 36:171-175

Bratbak G, Dundas I (1984) Bacterial dry matter content and biomass estimations. Appl environ Microbiol 48(4):755-757

Burkill PH, Mantoura RFC, Llewellyn CA, Owens NJP (1987) Microzooplankton grazing and selectivity of phytoplankton in coastal waters. Mar Biol 93:581-590

Cadée GC (1986) Recurrent and changing seasonal patterns in phytoplankton of the westernmost inlet of the Dutch Wadden Sea from 1969 to 1985. Mar Biol 93:281-289

Cadée GC (1992) Trends in Marsdiep phytoplankton. Neth Inst Sea Res Publ Ser 20:143-149

Cadée GC, Hegeman J (1986) Seasonal and annual variation in Phaeocystis pouchetii (Haptophyceae) in the westernmost inlet of the Wadden Sea during the 1973 to 1985 period. Neth J Sea Res 20(1):29-36

Caron DA, Lin Lim E, Miceli G, Waterbury JB, Valois FW (1991) Grazing and utilization of chroococcoid cyanobacteria and heterotrophic bacteria by protozoa in laboratory cultures and a coastal plankton community. Mar Ecol Prog Ser 76:205-217

Daan R (1989) Factors controlling the summer development of copepod populations in the Southern Bight of the North Sea. Neth J Sea Res 23(3):305-322

Davies AG, Madariaga I, de Bautista B, Fernández E (1992) The ecology of a coastal Phaeocystis bloom in the northwestern English Channel in 1990. J mar biol Ass UK 72: $691-708$

Eisma D. Kalf J (1987) Dispersal, concentration and deposition of suspended matter in the North Sea. J Geol Soc 144: $161-178$

Estep KW, Nejstgaard JCh, Skjoldal HR, Rey F (1990) Predation by copepods upon natural populations of Phaeocystis pouchetii as a function of the physiological state of the prey. Mar Ecol Prog Ser 67:235-249

Fenchel T (1982) Ecology of heterotrophic microflagellates. III. Adaptations to heterogenous environments. Mar Ecol Prog Ser 9:25-33

Fransz HG, Colebrook JM, Gambe JC, Krause M (1991) The zooplankton of the North Sea. Neth J Sea Res 20(1/2):1-52

Fransz HG, Gieskes WWC (1984) The unbalance of phytoplankton and copepods in the North Sea. Rapp P-v Réun Cons int Explor Mer 183:218-225

Fransz HG, van Arkel WG (1980) Zooplankton activity during and after the phytoplankton spring bloom at the central station in the FLEX box, northern North Sea, with special reference to the calanoid copepod Calanus finmarchicus (Gunn.). 'Meteor' Forsch-Ergebn A.22:113-121

Fransz HG, van Arkel WG (1983) Fluctuation and succession of common pelagic copepod species in the Dutch Wadden Sea. Oceanol Acta Sp:87-91

Frost BW (1972) Effects of size and concentration of food particles on the feeding behavior of the marine planktonic copepod Calanus pacificus. Limnol Oceanogr 17(6): $205-215$

Fukami K, Simidu U, Taga N (1981) Fluctuation of the communities of heterotrophic bacteria during the decomposition process of phytoplankton. J exp mar Biol Ecol 55: $171-184$

Gieskes WWC, Kraay GW (1977) Primary production and consumption of organic matter in the southern North Sea during the spring bloom of 1975. Neth J Sea Res 11(2): 146-167

Gifford DJ (1988) Impact of grazing by microzooplankton in the Northwest Arm of Halifax Harbour, Nova Scotia. Mar Ecol Prog Ser 47:249-258

Gifford DJ, Dagg MJ (1991) The microzooplankton-mesozooplankton link: consumptron of planktonic protozoa by the calanoid copepods Acartia tonsa Dana and Neocalanus plumchrus Murukawa. Mar microb Food Webs 5(1): $161-177$

Grimm N, Weisse T (1985) Die Temperaturabhängigkeit des Wachstums von Phaeocystis pouchetii (Haptophyceae) in Batchkulturen. Helgoländer wiss Meeresunters 39: $201-211$

Hansen B, Tande KS, Berggreen UC (1990) On the trophic fate of Phaeocystis pouchetii (Hariot). III. Functional responses in grazing demonstrated on juvenile stages of Calanus finmarchicus (Copepoda) fed diatoms and Phaeocystis. J Plankon Res 12(6):1173-1187

Hansen FC, Reckermann M, Klein Breteler WCM, Riegman R (1993) Phaeocystis blooming enhanced by copepod predation on protozoa: evidence from incubation experiments. Mar Ecol Prog Ser 102:51-57

Hansen FC, van Boekel WHM (1991) Grazing pressure of the calanoid copepod Temora longicornis on a Phaeocystis dominated spring bloom in a Dutch tidal inlet Mar Ecol Prog Ser 78:123-129

Hansen PJ (1992) Prey size selection, feeding rates and growth dynamics of heterotrophic dinoflagellates with special emphasis on Gyrodinium spirale. Mar Biol 114:327-334

Helder W, de Vries RTP (1979) An automatic phenol-hypochlorite method for the determination of ammonia in seaand brackish waters. Neth J Sea Res 13(1):154-160

Hobbie JE, Daley RJ, Jasper S (1977) Use of nucleopore filters for counting bacteria by fluorescence microscopy. Appl environ Microbiol 33(5):1225-1228

Holm-Hansen O, Lorenzen CJ, Holmes RW, Strickland JDH (1965) Fluorometric determination of chlorophyll. J Cons perm int Explor Mer 30(1):3-15

Joiris C, Billen G, Lancelot C, Daro MH, Mommaerts JP, Bertels A, Bossicart M, Nijs J (1982) A budget of carbon cycling in the Belgian coastal zone: relative roles of zooplankton, bacterioplankton and benthos in the utilization of primary production. Neth J Sea Res 16:260-275

Kayser $H$ (1970) Experimental-ecological investigations on Phaeocystis pouchetii (Haptophyceae): cultivation and waste water test. Helgoländer wiss Meeresunters 20: $195-212$

Kiørboe T, Kaas H, Kruse B, Møhlenberg F, Tiselius P, Ertebjerg $G$ (1990) The structure of the pelagic food web in relation to water column structure in the Skagerrak. Mar Ecol Prog Ser 59:19-32 
Klein Breteler WCM, Fransz HG, Gonzalez SR (1982) Growth and development of four calanoid copepod species under experimental and natural conditions. Neth J Sea Res 16: 195-207

Kranck K, Milligan TG (1988) Macroflocs from diatoms: in situ photography of particles in Bedford Basin, Nova Scotia. Mar Ecol Prog Ser 44:183-189

Kuipers BR, Gaedke U, Enserink L, Witte H (1990) Effect of ctenophore predation on mesozooplankton during a spring outburst of Pleurobrachia pileus. Neth J Sea Res 26(1): 111-124

Kuosa H (1991) Picoplanktonic algae in the northern Baltic Sea: seasonal dynamics and flagellate grazing. Mar Ecol Prog Ser 73:269-276

Laanbroek HJ, Verplanke JC, De Visscher PRM, De Vuyst R (1985) Distribution of phyto- and bacterioplankton growth and biomass parameters, dissolved inorganic nutrients and free amino acids during a spring bloom in the Oosterscheld basin, The Netherlands. Mar Ecol Prog Ser 25:1-11

Lancelot C, Billen G (1984) Activity of heterotrophic bacteria and its coupling to primary production during the spring phytoplankton bloom in the Southern Bight of the North Sea. Limnol Oceanogr 29(4):721-730

Lancelot C, Billen G, Barth H (1991) The dynamics of Phaeocystis blooms in nutrient enriched coastal zones. Water Pollution Research Report Series of the Environmental Research and Development Programme, Commission of the European Communilies, No 23, Brussels

Lancelot C, Mathot S (1987) Dynamics of a Phaeocystisdominated spring bloom in Belgian coastal waters. I. Phytoplanktonic activities and related parameters. Mar Ecol Prog Ser 37:239-248

Lancelot C, Mathot S, Owens NJP (1986) Modelling protein synthesis, a step to an accurate estimate of net primary production: Phaeocystis pouchetii colonies in Belgian coastal waters. Mar Ecol Prog Ser 32:193-202

Landry MR, Hassett RP (1982) Estimating the grazing impact of marine micro-zooplankton. Mar Biol 67:282-288

Mangelsdorf P (1972) Methodische Verbesserungen der Phosphat-Bestimmung im Meerwasser mit dem AutoAnalyzer insbesondere für den Bordbetrieb. Helgoländer wiss Meeresunters 23:376-382

MCManus GB, Ederington-Cantrell MC (1992) Phytoplankton pigments and growth rates, and microzooplankton grazing in a large temperate estuary. Mar Ecol Prog Ser 87:77-85

Nassogne A (1972) Etudes préliminaires sur le rôle du zooplancton dans la constistution et le transfert de la matière organique au sein de la chaine alimentaire. PhD thesis, University of Amsterdam

Nielsen TG, Løkkegaard B, Richardson K, Pedersen FB, Hansen L (1993) Structure of plankton communities in the Dogger bank area (North Sea) during a stratified situation. Mar Ecol Prog Ser 95:115-131

Nielsen TG, Richardson K (1989) Food chain structure of the North Sea plankton communities: seasonal variations of the role of the microbial loop. Mar Ecol Prog Ser 56:75-87

Paffenhöfer GA, Strickler JR, Alcaraz M (1982) Suspensiofeeding by herbivorous calanoid copepods: a cinematographic study. Mar Biol 67:193-199

Passow U (1991) Species-specific sedimentation and sinking velocities of diatoms. Mar Biol 108:449-455

Peinert $R$, Saure $A$, Stegmann $P$, Stienen $C$, Haardt $H_{\text {, }}$ Smetacek V (1982) Dynamics of primary production and sedimentation in a coastal ecosystem. Neth J Sea Res 16: $276-289$

Peperzak L (1993) Daily irradiance governs growth rate and colony formation of Phaeocystis (Prymnesiophyceael.
J Plankton Res 15(7):809-821

Pierce RW, Turner JT (1992) Ecology of planktonic ciliates in marine food webs. Rev aquat Sci 6(2):139-181

Putt $M$, Stoecker DK (1989) An experimentally determined carbon:volume ratio for marine 'oligotrichous' ciliates from estuarine and coastal waters. Limnol Oceanogr 34(6): $1097-1103$

Rassoulzadegan F (1982) Dependence of grazing rate, gross growth efficiency and food size range on temperature in a pelagic oligotrichous ciliate Lohmanniella spiralis Leeg, fed on naturally occurring particulate matter. Annls Inst océanogr, Paris 58(2):177-184

Reynolds CS, Thompson JM, Ferguson AJD, Wiseman SW (1982) Loss processes in the population dynamics of phytoplankton maintained in closed systems. J Plankton Res 4(3):561-600

Riebesell U (1989) Comparison of sinking and sedimentation rate measurements in a diatom winter/spring bloom. Mar Ecol Prog Ser 54:109-119

Ruebesell U (1991) Particle aggregation during a diatom bloom I. Physical aspects. Mar Ecol Prog Ser 69:273-280

Riegman R. Kuipers BR, Noordeloos AAM, Witie HJ (1993) Size-differential control of phytoplankton and the structure of plankton communities. Neth J Sea Res 31(3):255-265

Riegman R, Noordeloos AAM, Cadée GC (1992) Phaeocystis blooms and eutrophication of the continental coastal zones of the North Sea. Mar Biol 112:479 484

Rivier A, Brownlee DC, Sheldon RW, Rassoulzadegan F (1985) Growth of microzooplankton: a comparative study of bactivorous zooflagellates and ciliates. Mar microb Food Webs 1:51-60

Rousseau V, Mathot S, Lancelot C (1990) Calculating carbon biomass of Phaeocystis sp. from microscopic observations. Mar Biol 107:305-314

Schaumann K, Gerdes D, Hesse KJ (1988) Hydrographic and biological characteristics of a Noctiluca scintillans red tide in the German Bight, 1984. Meeresforschung 32:77-91

Sheldon RW, Niva P, Rassoulzadegan F (1986) An experimental investigation of a flagellate-ciliate-copepod food chain with some observations relevant to the linear biomass hypothesis. Limnol Oceanogr 31(1):184-188

Sherr EB, Sherr BF, Paffenhöfer GA (1986) Phagotrophic protozoa as food for metazoans: a 'missing' trophic link in marine pelagic food webs? Mar microb Food Webs 1(2): $61-80$

Simon M, Azam F (1989) Protein content and protein synthesis rates of planktonic marine bacteria. Mar Ecol Prog Ser. $51: 201-213$

Smetack VS (1985) Role of sinking diatom life-history cycles: ecological, evolutionary and geological significance. Mar Biol 84:239-251

Stoecker DK, Capuzzo JM (1990) Predation on protozoa: its importance to zooplankton. J Plankton Res 12(5):891-908

Stoecker DK, Egloff DA (1987) Predation by Acartia tonsa Dana on planktonic ciliates and rotifers. J exp mar Biol Ecol 110:53-68

Tande KS, Bàmstedt U (1987) On the trophic fate of Phaeocystis pouchetii. I. Copepod feeding rates on solitary cells and colonies of $P$. pouchetii. Sarsia 72:313-320

Technicon (1987) Nitrate/nitrite in water and seawater. Industrial Method 818-87T Technicon, New York

Thomsen J, Johnson KS, Petty RL (1983) Determination of reactive silicate in seawater by flow injection analysis. Analyt Chem 55:2378-2382

Turner JT, Bruno SF, Larson RJ, Staker RD, Sharma GM (1983) Seasonality of plankton assemblages in a temperate estuary. PSZN I: Mar Ecol 4(1):81-99 
Turner JT, Granéli E (1992) Zooplankton feeding ecology: grazing during enclosure studies of phytoplankton blooms from the west coast of Sweden. J exp mar Bıol Ecol 157:19-31

Uhlig G, Sahling G (1990) Long-term studies on Noctiluca scintillans in the German Bight. Population dynamics and red tide phenomena 1968-1988. Neth J Sea Res 25(1/2): $101-112$

Utermöhl H (1958) Zur Vervollkommnung der quantitativen Phytoplankton-Methodik. Mitt int Verein theor angew Limnol 9:1-39

van Boekel WHM (1992) Interactions of Phaeocystis sp. with organic compounds and the microbial foodweb. PhD thesis, University of Groningen

van Boekel WHM, Hansen FC, Riegman R, Bak RPM (1992) Lysis-finduced decline of a Phaeocystis spring bloom and coupling with the microbial foodweb. Mar Ecol Prog Ser 81:269-276

van Duyl FC, Bak RPM, Kop AJ, Nieuwland G (1990) Bacteria, auto- and heterotrophic nanoflagellates, and their relations in mixed frontal and stratified waters of the North Sea. Neth J Sea Res 26(1):97-109

van Wambeke F (1994) Influence of phytoplankton lysis or grazing on bacterial metabolism and trophic relationships. Microb Ecol 27:143-158

Veldhuis MJW, Admiraal W (1987) Influence of phosphate

This article was submitted to the editor depletion on the growth and colony formation of Phaeocystis pouchetii Mar Biol 95:47-54

Veldhuis MJW, Colijn F, Venekamp LAH (1986) The spring bloom of Phaeocystis pouchetii (Haptophyceae) in Dutch coastal waters. Neth J Sea Res 21 (1):37-48

Verity PG (1985) Grazing, respiration, excretion, and growth rates of tintinnids. Limnol Oceanogr 30(6):1268-1282

Wassmann P (1994) Significance of sedimentation for the termination of Phaeocystis blooms. J mar Syst 5:81-100

Wassmann P, Vernet M, Mitchell BG, Rey F (1990) Mass sedimentation of Phaeocystis pouchetii in the Barents Sea. Mar Ecol Prog Ser 66:183-195

Weisse I (1990) Trophic interactions among heterotrophic microplankton, nanoplankton, and bacteria in Lake Constance. Hydrobiologia 191:111-122

Weisse T, Scheffel-Möser U (1990) Growth and grazing loss rates in single-celled Phaeocystis sp. (Prymnesiophyceae). Mar Biol 106:153-158

White JR, Roman MR (1992) Egg production by the calanoid copepod Acartia tonsa in the mesohaline Chesapeake Bay: the importance of food resources and temperature. Mar Ecol Prog Ser 86:239-249

Wiadnyana NN, Rassoulzadegan F (1989) Selective feeding of Acartia clausi and Centropages typicus on microzooplankton. Mar Ecol Prog Ser 53:37-45

Manuscript first received: October 4, 1994

Revised version accepted: February 14, 1995 